\title{
PELATIHAN DAN IKLIM ORGANISASI TERHADAP KEBERHASILAN USAHA PERIKANAN MASYARAKAT (STUDI KASUS PADA DINAS PETERNAKAN DAN PERIKANAN (BIDANG PERIKANAN) KOTA SUNGAI PENUH
}

\begin{abstract}
The research is proposed to test the influence of Training and Organizational Climate on the Success of Fisheries. The population in this study is the Sungai Penuh City community which has a total of 120 fisheries businesses. Furthermore, by using the Slovin formula, a sample size of 92 businesses was selected with a sampling technique based on Proportional Cluster Random Sampling. This study uses primary data and secondary data. Data analysis techniques used are path analysis and test hypotheses using t test with data analysis using SPSS version 20. The results of the study based on showing that partially the Training and Organizational Climate has a positive and significant effect on Business Success. The results also show that the Organizational Climate variable acts as an intervening variable between Training and Business.
\end{abstract}

Keywords : Training, Organizational Climate, Success of Fisheries

\section{LATAR BELAKANG.}

Keberhasilan hanya diperoleh jika manusia melakukan segala sesuatu dengan sebaik-baiknya. Sukses hanya bisa dicapai melalui usaha yang sungguh-sungguh. Keberhasilan usaha menurut Suryana (2003:285) adalah keberhasilan dari bisnis dalam mencapai tujuanya. Menurut Noor (2007:397) mengungkapkan bahwa keberhasilan usaha pada hakikatnya adalah keberhasilan dari bisnis mencapai tujuanyaTujuan penghabisan dari setiap orang sukses adalah mencapai kebahagiaan dalam dirinya. Kebahagiaan adalah kepuasan derajat tertinggi dalam diri seseorang. Kepuasan diri itu terjadi karena seseorang telah berprestasi. Kebahagiaan berkembang dalam diri seseorang berdasarkan rasa puas diri yang mencapai puncaknya karena telah berhasil melakukan sesuatu hal secara baik, dengan perasaan senang dan merasa bangga terhadap hasilnya.

Dinas Peternakan dan Perikanan Kota Sungai Penuh merupakan dinas yang melayani masyarakat di bidang peternakan dan perikanan. Dinas peternakan dan perikanan Kota Sungai Penuh terdiri dari beberapa bagian salah satunya bidang perikanan. Pelayanan mengenai bidang perikanan masyarakat Kota Sungai Penuh sangat dibutuhkan oleh masyarakat karena masyarakat Kota Sungai Penuh pada umumnya memiliki usaha perikanan. Pegawai bidang Perikanan Kota Sungai Penuh harus memiliki pelatihan dan iklim organisasi yang tinggi karena pegawai merupakan personil yang langsung terjun ke lapangan untuk memberikan penyuluhan dan membantu masyarakat dalam usaha perikanan.

Keberhasilan usaha masyarakat Kota Sungai Penuh dalam bidang perikanan cukup banyak. Pengembangan usaha masyarakat tersebut tentunya tidak lepas dari pembinaan yang diberikan oleh bidang perikanan Kota Sungai Penuh. Oleh karena itu pegawai harus memberikan pelayanan kepada masyarakat karena mata pencaharian masyakarat pada umumnya bergerak di bidang perikanan. Keberhasilan usaha masyarakat dalam bidang 
perikanan dapat dilihat dari data hasil produksi masyarakat seperti yang terlihat dalam tabel 1.1 dibawah ini :

Tabel 1

\begin{tabular}{clccc}
\hline \multirow{2}{*}{ No } & & \multicolumn{3}{c}{ Satuan : Ton } \\
\cline { 3 - 5 } & & $\mathbf{2 0 1 5}$ & $\mathbf{2 0 1 6}$ & $\mathbf{2 0 1 7}$ \\
\cline { 3 - 5 } 1 & Tanah Kampung & 40,20 & 42,00 & 38,00 \\
\hline 2 & Kumun Debai & 40,50 & 42,00 & 42,02 \\
\hline 3 & Sungai Penuh & 6,10 & 6,30 & 8,23 \\
\hline 4 & Hamparan Rawang & 37,30 & 52,50 & 19,36 \\
\hline 5 & Pesisir Bukit & 20,50 & 6,30 & 23,66 \\
\hline 6 & Sungai Bungkal & 13,50 & 14,70 & 23,63 \\
\hline 7 & Pondok Tinggi & 40,70 & 14,70 & 40,96 \\
\hline 8 & Koto Baru & 31,20 & 31,50 & 6,00 \\
\hline & Total & $\mathbf{2 3 0 , 0 0}$ & $\mathbf{2 1 0 , 0 0}$ & $\mathbf{2 0 1 , 8 6}$ \\
\hline & & Produksi Pengolahan Ikan & \\
\hline 1 & Kota Sungai Penuh & 60,00 & 72,00 & 72,00 \\
\hline
\end{tabular}

Sumber : Dinas Peternakan dan Perikanan Kota Sungai Penuh Tahun 2018

Berdasarkan Tabel 1.1 terlihat adanya peningkatan angka kemangkiran dari bulan Juli ke Agustus 2012 yaitu dari 1,5\% menjadi 1,6 \%. Artinya bahwa dari 286 pegawai yang bekerja pada bulan tersebut, 1,6 \% diantaranya tidak masuk kerja dan bisa diduga ada masalah yang berkaitan dengan kepuasan kerja. Pada bulan Agustus ini lah tingkat kemangkiran tertinggi sepanjang tahun anggaran 2012.

Secara keseluruhan produksi budidaya ikan pada Kota Sungai Penuh mengalami penurunan dari tahun 2015 ke tahun 2017, dimana pada tahun 2015 produksi budi daya ikan sebesar 230,00 ton kemudian menurun pada tahun 2016 menjadi 210,00 ton dan kembali menurun pada tahun 2017 menjadi 201,86 ton. Sementara untuk produksi pengolahan ikan mengalami sedikit kenaikan yaitu 60,00 ton ditahun 2015 kemudian naik 72,00 ton namun pada tahun 2017 tidak mengalami kenaikan atau penurunan. Penurunan hasil produksi masyarakat tentunya dipengaruhi oleh peran pegawai bidang Perikanan Kota Sungai Penuh dalam memberikan penyuluhan kepada masyarakat dalam meningkatkan usahanya. Di duga kurang maksimalnya pegawai terutama bagian lapangan dalam memberikan pengetahuan kepada masyarakat, hal ini disebabkan diantaranya karena sebagian pegawai memiliki latar belakang yang tidak sesuai dengan keahliannya sementara yang ahli dibidangnya tidak dimanfaatkan potensinya. Rendahnya pengetahuan masyarakat dalam mengelola usahanya menyebabkan usahanya mengalami pasang surut. Data yang penulis dapatkan dimana usaha dibidang perikanan kolam ikan banyak mengalami kerusakan, rata-rata kolam yang rusak setiap kelompok usaha ada 2 sampai 10 kolam. Adanya ternak yang mati mendadak atau sakit menyebabkan kerugian bagi masyarakat. Untuk itu sangat diperlukan bantuan dari bidang Perikanan dalam meningkatkan keberhasilan usaha perikanan masyarakat.

Pentingnya pegawai bidang perikanan pada Dinas Peternakan dan Perikanan Kota Sungai Penuh sangat berpengaruh terhadap pelaksanaan tujuan instansi itu, yaitu untuk meningkatkan pelayanan terhadap para masyarakat terutama dalam proses pengawasan dan pembinaan terhadap kebutuhan informasi. Dalam meningkatkan keberhasilan usaha perikanan masyarakat oleh bidang perikanan pada Dinas Peternakan dan Perikanan Kota Sungai Penuh, faktor yang berkemungkinan paling dominan mempengaruhi adalah pelatihan dan iklim organisasi. 
Menurut Nitisemito (2001), pelatihan adalah suatu kegiatan dari perusahaan yang bermaksud untuk dapat memperbaiki dan mengembangkan sikap, tingkah laku, keterampilan dan pengetahuan dari para karyawannya sesuai dengan kegiatan dari perusahaan yang bersangkutan. Fenomena yang berkaitan dengan pelatihan pegawai pada Dinas Peternakan dan Perikanan Kota Sungai Penuh adalah sedikitnya pegawai yang mengikuti pelatihan. Hal ini tentu saja mengakibatkan kurangnya pengetahuan dan skill yang dimiliki pegawai dalam bekerja. Pelatihan sangat penting bagi pegawai karena merupakan kebutuhan-kebutuhan yang diperlukan pegawai dalam bekerja. Sedikitnya pegawai dalam mengikuti pelatihan kurang dapat membantu pegawai dalam menyelesaikan pekerjaan dan kurang dapat membantu pegawai mengahadapi tantangan masa yang akan datang.

Pada tabel berikut ini dapat dilihat data pegawai yang ikut pelatihan dan dana yang digunakan untuk pelatihan tersebut yaitu sebagai berikut :

Tabel 2

\begin{tabular}{|c|c|c|c|}
\hline No & Pelatihan & Jumlah Peserta & Jumlah Dana Pelatihan \\
\hline 1 & $\begin{array}{l}\text { Pelatihan Membuat Pakan } \\
\text { Ikan }\end{array}$ & 4 Orang & Rp. 20.000.000 \\
\hline 2 & $\begin{array}{l}\text { Pelatihan Cara Budidaya } \\
\text { ikan yang baik }\end{array}$ & 4 Orang & Rp. 20.000 .000 \\
\hline
\end{tabular}

Pada tabel 2 terlihat bahwa pelatihan yang di ikuti pegawai sepanjang tahun 2018 sedikit sekali. Pegawai yang ikut hanya 4 orang. Pegawai yang mengikuti pelatihan terkadang tidak sesuai dengan latar belakang pendidikannya. Hal ini menyebabkan pegawai tidak semangat dalam mengikuti pelatihan sehingga pelatihan yang diikuti tidak mendapatkan hasil yang maksimal. Pegawai kurang mampu menguasai bidang tugas yang dikerjakan sehingga pekerjaan tidak menjadi efektif dan efisien. Sementara hasil pelatihan yang diberikan kepada pegawai akan diterapkan lagi kepada masyarakat untuk meningkatkan usaha perikanan masyarakat.

Menurut Wirawan (2008:121) Iklim organisasi merupakan persepsi anggota organisasi secara individual dan kelompok dan mereka yang secara tetap berhubungan dengan organisasi mengenai apa yang terjadi di lingkungan internal organisasi secara rutin, yang mempengaruhi sikap dan perilaku organisasi dan kinerja anggota organisasi yang kemudian menentukan kinerja organisasi. Fenomena yang penulis temukan melalui pra research berkaitan dengan iklim organisasi, dimana sebanyak $70,59 \%$ responden menjawab komunikasi antar pegawai kurang harmonis, sebanyak $60,78 \%$ responden menjawab suasana kerja tidak kondusif dan sebanyak $62,75 \%$ responden menjawab kerjasama antar pegawai tidak baik. Hal tersebut dapat dilihat pada tabel 1.1 Persentase fenomena iklim organisasi berikut:

Tabel 3

\begin{tabular}{clcc}
\hline \multirow{2}{*}{ No } & \multirow{2}{*}{ Fenomena } & \multicolumn{2}{c}{ Persentase } \\
\cline { 3 - 4 } & Komunikasi antar pegawai kurang harmonis & $70,59 \%$ & Tidak \\
\hline 1 & Suasana kerja tidak kondusif & $60,78 \%$ & $39,22 \%$ \\
\hline 2 & Kerjasama antar pegawai tidak baik & $62,75 \%$ & $37,25 \%$ \\
\hline Sumber: & Data survey awal April, 2018 & \multicolumn{2}{c}{}
\end{tabular}


Pegawai bidang perikanan di Dinas Peternakan dan Perikanan Kota Sungai Penuh terdiri dari beberapa pegawai yang ditempatkan dari Instansi Pusat. Pegawai tersebut dikirimkan untuk membantu Dinas Peternakan dan Perikanan Kota Sungai Penuh dalam memaksimalkan pekerjaannya khususnya di bagian perikanan. Hal ini tentu saja menyebabkan perubahan iklim organisasi di bagian perikanan karena pegawai dari instansi pusat membawa iklim organisasi yang baru dibagian perikanan. Misalnya dalam suasana bekerja pegawai dari intansi pusat terbiasa bekerja cepat sehingga menuntut pegawai lain untuk bekerja cepat.

Berdasarkan latar belakang masalah dapat dirumuskan masalah sebagai berikut: (1) Bagaimana pengaruh pelatihan pegawai terhadap keberhasilan usaha perikanan masyarakat Kota Sungai Penuh ? (2) Bagaimana pengaruh iklim organisasi terhadap keberhasilan usaha perikanan masyarakat Kota Sungai Penuh? (3) Bagaimana pengaruh pelatihan terhadap iklim organisasi Pegawai Bidang Perikanan Pada Dinas Peternakan dan Perikanan Kota Sungai Penuh? (4) Bagaimanakah peranan iklim organisasi sebagai variabel intervening antara pelatihan pegawai dan keberhasilan usaha perikanan masyarakat Kota Sungai Penuh?

\section{METODE PENELITIAN}

Desain penelitian ini adalah penelitian kausal yaitu penelitian yang menganalisis hubungan antara satu variabel atau lebih dengan variabel lainnya (Bougie, 2010). Dalam konteks penelitian ini, variabel-varibel yang dimaksud adalah pelatihan, iklim organisasi dan keberhasilan usaha perikanan masyarakat. Adapun objek penelitian ini adalah masyarakat yang memiliki usaha perikanan di Kota Sungai Penuh.

Teknik pengambilan sampel Proportional Cluster Random Sampling yaitu pengambilan anggota sample dari populasi dilakukan secara acak tanpa memperhatikan stara yang ada dalam populasi itu". Jumlah sampel ditentukan berdasarkan pada perhitungan dari rumus Slovin dengan tingkat kesalahan yang ditoleransi sebesar 5\%. Dengan menggunakan rumus tersebut maka diperoleh jumlah sampel 92 responden masyarakat yang memiliki usaha perikanan. Jenis dan sumber data dalam penelitian in menggunakkan data primer dan data sekunder. Teknik pengumpulan data ini dilakukan melalui kuisioner. Instrumen penelitian ini adalah menggunakkan kuisioner denga skala likert. Sebelum kuisioner digunakkan, terlebih dahulu digunakkan uji validitas dan reabilitas. Teknik analisis data dalam penelitian ini menggunakkan analisis jalur (path analysis). Selanjutnya dilakukan uji hipotesis dengan uji t dan signifikansi $\alpha=0.05$.

\section{HASIL DAN PEMBAHASAN}

Sebelum menggunakan analisis jalur dilakukan uji prasyarat yaitu (1) uji normalitas (2) uji multikolinearitas (3) uji heteroskedastisitas. Dari hasil uji tersebut memenuhi syarat untuk menggunakkan analisis jalur. Hasil analisis jalur dapat diliht pada gambar dibawah ini :

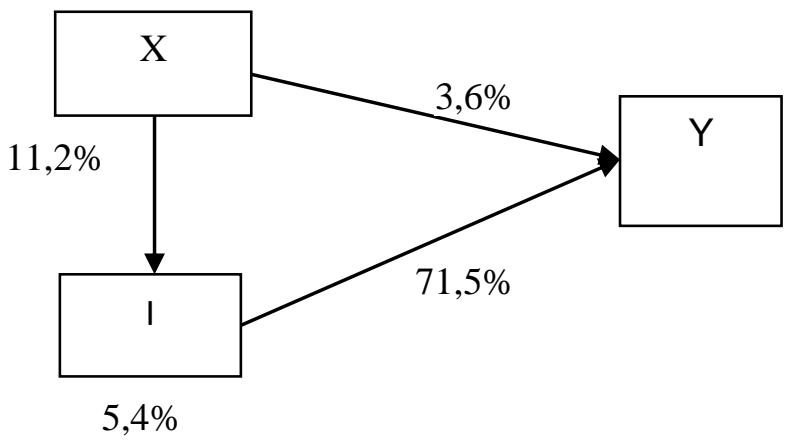

Gambar. 2

Hasil Analisis Jalur 


\section{PEMBAHASAN}

\section{Pengaruh Pelatihan (X) Terhadap Keberhasilan Usaha (Y)}

Bila dilihat dari hasil TCR untuk variabel Pelatihan sebesar $65 \%$ atau masuk dalam kategori Cukup Baik, maka harus ditingkatkan dengan sangat maksimal. Sementara itu hasil hipotesis 1 menunjukkan bahwa pelatihan berpengaruh positif dan signifikan terhadap Keberhasilan Usaha pada Dinas Peternakan dan Perikanan (Bidang Perikanan) Sungai Penuh. Dengan demikian apabila pelatihan pegawai ditingkatkan maka akan semakin meningkat pula Keberhasilan Usaha.

Hasil analisis regresi linear sederhana pengaruh pelatihan terhadap keberhasilan usaha masyarakat memiliki koefisien sebesar 0.192. Hal ini menunjukkan, bahwa pelatihan mempunyai pengaruh terhadap keberhasilan usaha masyarakat sebesar 0,192 dan karakatristik individu memiliki pengaruh yang positif dan signifikan terhadap keberhasilan usaha masyarakat sehingga semakin tinggi pelatihan yang dimiliki pegawai maka ada kecenderungan semakin tinggi keberhasilan usaha masyarakat. Jika pelatihan ditingkatkan maka keberhasilan usaha masyarakat akan mengalami peningkatan sebesar 19,2\%.

Hasil penelitian sejalan dengan penelitian yang dilakukan oleh Ruru (2015) yang berjudul "Pengaruh Iklim Organisasi Terhadap Efektifitas Pelayanan Publik di Kecamatan Taliabu Utara Kabupaten Kepulauan Sula". Hasil penelitian menunjukkan berdasarkan analisis korelasi sederhana (product moment) bahwa iklim organisasi mempunyai korelasi dan derajat penentu/pengaruh signifikan terhadap efektivitas pelayanan publik di kantor Camat Taliabu Utara Kabupaten Kepulauan Sula. Hal ini memberi kesimpulan bahwa iklim organisasi merupakan salah satu faktor penentu efektivitas pelayanan publik; bahwa semakin baik dan kondutif iklim organisasi maka akan semakin baik atau meningkat efektivitas pelayanan publik

Jadi jika Dinas Perternakan dan Perikanan (Bidang Perikanan) Kota Sungai Penuh ingin meningkatkan keberhasilan usaha masyarakat maka harus meningkatkan pelatihan pegawainya, karena jika tidak maka keberhasilan usaha masyarakat semakin menurun. Pelatihan yang baik dimiliki pegawai cenderung akan meningkatkan keberhasilan usaha masyarakat, demikian pula bila terjadi sebaliknya.

\section{Pengaruh Iklim Organisasi (I) terhadap Keberhasilan Usaha (Y)}

Bila dilihat dari hasil TCR untuk variabel Iklim Organisasi sebesar 66,42\% atau masuk dalam kategor Cukup Baik, maka harus ditingkatkan dengan sangat maksimal. Sementara itu hasil hipotesis 2 menunjukkan bahwa Iklim Organisasi berpengaruh positif dan signifikan terhadap Keberhasilan Usaha pada Dinas Peternakan dan Perikanan (Bidang Perikanan) Sungai Penuh. Dengan demikian apabila Iklim Organisasi pegawai ditingkatkan maka akan semakin meningkat pula Keberhasilan Usaha

Hasil analisis regresi linear sederhana pengaruh iklim organisasi terhadap keberhasilan usaha masyarakat memiliki koefisien sebesar 0,846. Hal ini menunjukkan, bahwa iklim organisasi mempunyai pengaruh terhadap keberhasilan usaha masyarakat sebesar 0,846 dan iklim organisasi memiliki pengaruh yang positif dan signifikan terhadap keberhasilan usaha masyarakat sehingga semakin tinggi iklim organisasi yang dimiliki pegawai maka ada kecenderungan semakin tinggi keberhasilan usaha masyarakat. Jika iklim organisasi ditingkatkan maka keberhasilan usaha masyarakat akan mengalami peningkatan sebesar $84,6 \%$. 
Hasil penelitian sejalan dengan penelitian yang dilakukan oleh Azwar yang berjudul " Hubungan antara iklim organisasi, pelatihan dan kompensasi dengan kepuasan kerja pegawai pada lingkungan Hotel Sahid Jaya di Jakarta. Hasil Penelitian menunjukkan bahwa baik secara individual maupun simultan kepuasan kerja pegawai Hotel dipengaruhi oleh iklim organisasi, pelatihan dan kompensasi yang sangat signifikan. Secara keseluruhan ketiga variabel tersebut (iklim organisasi, pelatihan dan kompensasi) memberikan kontribusi sebesar $84 \%$ terhadap kepuasan kerja karyawan

Jadi jika Dinas Peternakan dan Perikanan (Bidang Perikanan) Kota Sungai Penuh ingin meningkatkan keberhasilan usaha masyarakat maka harus meningkatkan iklim organisasi pegawainya, karena jika tidak maka keberhasilan usaha masyarakat semakin menurun. Iklim organisasi yang baik dimiliki pegawai cenderung akan meningkatkan keberhasilan usaha masyarakat, demikian pula bila terjadi sebaliknya.

\section{Pengaruh Pelatihan (X) terhadap Iklim Organisasi (I)}

Hasil analisis regresi linear sederhana pengaruh pelatihan terhadap iklim organisasi memiliki koefisien sebesar 0,335. Hal ini menunjukkan, bahwa pelatihan mempunyai pengaruh terhadap iklim organisasi sebesar 0,335 dan pelatihan memiliki pengaruh yang positif dan signifikan terhadap iklim organisasi sehingga semakin tinggi pelatihan yang dimiliki pegawai maka ada kecenderungan semakin tinggi iklim organisasi. Jika pelatihan ditingkatkan maka iklim organisasi akan mengalami peningkatan sebesar 33,5\%.

Hasil penelitian sejalan dengan penelitian yang dilakukan oleh Komarudin (2017) yang berjudul "Pengaruh Pelatihan Terhadap Iklim organisasi Fasilitator (Survey di PPPPTKIPA Bandung)". Hasil penelitian ini menunjukkan bahwa pelatihan memiliki pengaruh signifikan terhadap iklim organisasi fasilitator.

Jadi jika Dinas Perternakan dan Perikanan (Bidang Perikanan) Kota Sungai Penuh ingin meningkatkan iklim organisasi maka harus meningkatkan pelatihan pegawainya, karena jika tidak maka iklim organisasi semakin menurun. Pelatihan yang baik dimiliki pegawai cenderung akan meningkatkan iklim organisasi, demikian pula bila terjadi sebaliknya

\section{Pengaruh Iklim Organisasi sebagai variabel Intervening antara Pelatihan dan Keberhasilan Usaha}

Hasil analisis jalur menunjukkan bahwa pelatihan dapat berpengaruh langsung terhadap keberhasilan usaha dan dapat berpengaruh tidak langsung terhadap keberhasilan usaha melalui iklim organisasi yang merupakan variabel intervening antara pelatihan terhadap keberhasilan usaha. Besarnya pengaruh langsung pelatihan terhadap keberhasilan usaha sebesar 3,6\% artinya jika pelatihan yang diberikan meningkat 3,6\% maka keberhasilan usaha akan meningkat sebesar 3,6\%. Besarnya pengaruh pelatihan terhadap iklim organisasi sebesar 11,2\% artinya jika pelatihan yang diberikan meningkat 11,2 \% maka iklim organisasi juga akan meningkat sebesar $11,2 \%$. Besarnya pengaruh iklim organisasi terhadap keberhasilan usaha sebesar $71,5 \%$ artinya jika iklim organisasi yang diberikan meningkat 71,5\% maka keberhasilan usaha juga akan meningkat sebesar 71,5\%. Pengaruh iklim organisasi terhadap keberhasilan usaha memiliki pengaruh yang paling besar dibandingkan pelatihan terhadap keberhasilan usaha, oleh karena itu Dinas Peternakan dan Perikanan Kota Sungai Penuh harus lebih meningkatkan iklim organisasinya dibandingkan pelatihan.

Pengaruh tidak langsung pelatihan terhadap keberhasilan usaha melalui iklim organisasi adalah sebesar 5,4\%. Artinya semakin tinggi pelatihan akan menyebabkan 
tingginya iklim organisasi dan kemudian akan menyebabkan tingginya keberhasilan usaha dan begitu juga sebaliknya jika pelatihan semakin rendah akan menyebabkan rendahnya iklim organisasi dan kemudian akan menyebabkan rendahnya keberhasilan usaha.

Hasil penelitian sejalan dengan penelitian yang dilakukan Ramadhani yang berjudul "Pengaruh Sumber Daya Manusia, Pendidikan Pelatihan dan Iklim Organisasi terhadap kinerja pegawai Balai Pelatihan dan Kesehatan (BAPELKES) Provinsi Kalimantan Selatan. Berdasarkan penelitian yang dilakukan dapat diketahui bahwa secara simultan variabel independent Kualitas Sumber Daya Manusia (X1), Pendidikan Pelatihan (X2) dan Iklim Organisasi (X3) memiliki pengaruh yang sangat signifikan terhadap variabel dependent Kinerja Pegawai (Y).

Jadi jika pelatihan meningkat maka akan meningkatkan iklim organisasi sehingga akan meningkatkan keberhasilan usaha masyarakat. Pelatihan yang baik dimiliki pegawai cenderung akan meningkatkan iklim organisasi kemudian akan meningkatkan keberhasilan usaha masyarakat, demikian pula bila terjadi sebaliknya jika pelatihan rendah dimiliki pegawai cenderung akan menurunkan iklim organisasi kemudian akan menurunkan keberhasilan usaha masyarakat.

\section{KESIMPULAN DAN SARAN}

\section{Kesimpulan}

Berdasarkan temuan penelitian yang telah diuraikan pada bab sebelumnya, maka dapat dikemukakan beberapa kesimpulan sebagai berikut: (1) Pelatihan Dinas Peternakan dan Perikanan (Bidang Perikanan) Sungai Penuh menurut masyarakat masih termasuk kedalam kategori cukup baik, tingkat capaian responden (TCR) sebesar 65\%. Hal ini menunjukkan bahwa pelatihan berada pada kategori cukup baik. Dengan demikian dapat dikatakan bahwa masyarakat cukup baik dalam menerima pelatihan yang diberikan pegawai Dinas Peternakan dan Perikanan (Bidang Perikanan) Sungai Penuh. (2) Iklim Organisasi pada Dinas Peternakan dan Perikanan (Bidang Perikanan) Sungai Penuh menurut masyarakat masih termasuk kedalam kategori cukup baik, dengan tingkat capain responden (TCR) sebesar 66,24\%. Hal ini menunjukkan bahwa iklim organisasi berada pada kategori cukup baik. Dengan demikian dapat dikatakan bahwa masyarakat cukup baik dalam merespon iklim organisasi Dinas Peternakan dan Perikanan (Bidang Perikanan) Sungai Penuh. (3) Keberhasilan Usaha dalam menerima layanan pada Dinas Peternakan dan Perikanan (Bidang Perikanan) Sungai Penuh termasuk kedalam kategori cukup baik, dengan tingkat capain responden (TCR) sebesar 68,81\%. Hal ini menunjukkan bahwa keberhasilan usaha berada pada kategori cukup baik. Dengan demikian dapat dikatakan bahwa dengan pelatihan dan iklim organisasi dari Dinas Peternakan dan Perikanan (Bidang Perikanan) Sungai Penuh memberikan keberhasilan usaha kepada masyarakat yang cukup baik. (4)Terdapat pengaruh positif dan signifikan variabel pelatihan terhadap Keberhasilan Usaha yang dibuktikan dengan koefisien sebesar 0,192 dengan nilai thitung >ttabel $(18,372$ $>$ 1.98667). Artinya semakin baik pelatihan akan semakin tinggi tingkat Keberhasilan Usaha dalam menerima layanan pada Dinas Peternakan dan Perikanan (Bidang Perikanan) Kota Sungai Penuh. Oleh karean itu, hipotesis pertama diterima. (5) Terdapat pengaruh positif dan signifikan variabel Iklim Organisasi terhadap Keberhasilan Usaha yang dibuktikan dengan koefisien sebesar 0,846 dengan nilai thitung>ttabel $(15,982>1.98667)$. Artinya semakin baik Iklim Organisasi akan semakin tinggi tingkat Keberhasilan Usaha dalam menerima layanan pada Dinas Peternakan dan Perikanan (Bidang Perikanan) Kota Sungai Penuh. Oleh karena itu, hipotesis kedua diterima. (6)Terdapat pengaruh positif dan signifikan variabel pelatihan terhadap Iklim Organisasi yang dibuktikan dengan koefisien sebesar 0,335 dengan nilai thitung>ttabel $(3,760>1.98698)$. Artinya semakin baik 
pelatihan akan semakin tinggi Keberhasilan Usaha dalam menerima layanan pada Dinas Peternakan dan Perikanan (Bidang Perikanan) Kota Sungai Penuh. Oleh karena itu, hipotesis ketiga diterima. (7)Hasil analisis jalur menunjukkan bahwa pelatihan dapat berpengaruh langsung terhadap keberhasilan usaha dan dapat berpengaruh tidak langsung terhadap keberhasian usaha melalui iklim organisasi yang merupakan variabel intervening antara pealtihan terhadap keberhasilan usaha. (8) Pengaruh tidak langsung pelatihan terhadap keberhasilan usaha melalui iklim organisasi adalah sebesar 5,4\%. Artinya semakin tinggi pelatihan akan menyebabkan tingginya iklim organisasi dan kemudian akan menyebabkan tingginya keberhasilan usaha dan begitu juga sebaliknya jika pelatihan semakin rendah akan menyebabkan rendahnya iklim organisasi dan kemudian akan menyebabkan rendahnya keberhasilan usaha.

\section{Saran-saran}

Berdasarkan hasil analisis dan pembahasan yang telah penulis sampaikan sebelumnya, berikut ini dapat disampaikan beberapa saran kepada Dinas Peternakan dan Perikanan (Bidang Perikanan) Sungai Penuh berikut: (1) Sehubungan dengan peningkatan Keberhasilan Usaha, maka Daya Saing dapat ditingkatkan dengan meningkatkan usaha masyarakat Perikanan dan memberi bantuan kepada masyarakat untuk bisa bersaing dengan usaha sejenis dari daerah lain. (2) Meningkatkan pelatihan pegawai diantaranya dengan cara meningkatkan prinsip - prinsip belajar dimana pelatihan yang diikuti pegawai dapat membuat pekerjaan diselesaikan dengan efektif dan efisien, pelatihan yang diikuti dapat mempersiapkan pegawai untuk menghadapi tantangan di masa yang akan datang. (3) Untuk meningkatkan Iklim Organisasi diantaranya dengan cara memberikan simpatik dan memberi dukungan sesama pegawai dengan cara meningkatkan ketanggapan dalam menangani keluhan usaha masyarakatdan pegawai bersikap adil dalam melayani masyarakat

\section{UCAPAN TERIMA KASIH}

Terima kasih atas dukungan materil maupun non materil dan semangat yang diberikan oleh Kepala Dinas dan pegawai Kantor Dinas Peternakan dan Perikanan Kota Sungai Penuh. Tidak lupa pula ucapan terima kasih saya haturkan kepada keluarga saya yang selalu memberikan motivasi dan doa untuk kelancaran karir saya. Paling utama saya panjatkan rasa syukur kepada Allah SWT yang memberikan kesehatan, kesempatan, kemudahan-kemudahan dan kelancaran hingga penelitian ini dapat diselesaikan.

\section{DAFTAR PUSTAKA}

Alvajrin Ramadhani yang berjudul "Pengaruh Sumber Daya Manusia, Pendidikan Pelatihan dan Iklim Organisasi terhadap kinerja pegawai Balai Pelatihan dan Kesehatan (BAPELKES) Provinsi Kalimantan Selatan.

Ambron Sius Mamo, Patar Rumapea Joorie Ruru. 2015. Pengaruh Iklim Organisasi Terhadap Efektifitas Pelayanan Publik di Kecamatan Taliabu Utara Kabupaten Kepulauan Sula. Journal Administrasi Publik Vol. 4 No.32 (2015), https://ejournal.unsrat.ac.id/index.php/JAP/issue/view/1167.

Henry Faizal Noor. 2007. Ekonomi Manajerial. Jakarta : PT. Raja Grafindo Persada.. 
Muchlus Azwar. 2010. Hubungan antara iklim organisasi, pelatihan dan kompensasi dengan kepuasan kerja pegawai pada lingkungan Hotel Sahid Jaya di Jakarta. Tesis : Universitas Indonesia.

Nitisemito, Alex S. 2001. “Manajemen Personalia” Cetakan ke -7 Ghalia Indonesia.

Suryana. (2003). Kewirausahan: Pedoman praktis, kiat dan proses menuju sukses (Edisi Revisi). Jakarta: Salemba Empat.

Wirawan. 2008. Budaya dan Iklim Organisasi. Jakarta: Salemba Empat

Yudistira, D. S., \& Susanti, F. (2019). Pengaruh Motivasi Kerja Dan Budaya Kerja Terhadap Kinerja Karyawan Dinas Pemberdayaan Masyarakat Dan Desa, Pengendalian Penduduk Dan Keluarga Berencana Kabupaten Pesisir Selatan. https://doi.org/10.31227/osf.io/jk54m

Ridho, M., \& Susanti, F. (2019). Pengaruh Stres Kerja Dan Motivasi Kerja Terhadap Kepuasan Kerja Pada Karyawan Bank Mandiri Syariah Cabang Padang. https://doi.org/10.31227/osf.io/pa2cg

Lubis, A. Y. O., \& Susanti, F. (2019). Pengaruh Gaya Kepemimpinan Dan Kompensasi Terhadap Prestasi Kerja Karyawan (Studi pada PT Japfa Comfeed Indonesia (JCI) Tbk Devisi Fam 1. https://doi.org/10.31227/osf.io/7tbrg

Aldi, Y., \& Susanti, F. (2019). Pengaruh Stress Kerja Dan Motivasi Kerja Terhadap Prestasi Kerja Karyawan Pada PT. Frisian Flag Indonesia Wilayah Padang. https://doi.org/10.31227/osf.io/et4rn

Widodo, B. H., \& Susanti, F. (2019). Pengaruh Human Relation (Hubungan Antar Manusia), Lingkungan kerja Terhadap Etos Kerja karyawan (Studi Kasus Pada PT. Pelindo Teluk Bayur Padang ). https://doi.org/10.31227/osf.io/dxm8a

Junaidi, R., \& Susanti, F. (2019). Pengaruh Gaya Kepemimpinan Dan Budaya Organisasi Terhadap Kinerja Pegawai Pada UPTD Baltekkomdik Dinas Pendidikan Provinsi Sumatera Barat. https://doi.org/10.31227/osf.io/bzq75

Selamat, S. Heryanto, H. (2019). Affecting Factors In Employee Performance Koto Baru SubDistrict, Dharmasraya District. Archives of Business Research 7 (7), 142-154

Ermayenti, E. Heryanto, H. (2019). The Effect Of Competence And Discipline Of Work On Public Satisfaction In The Regional Office Of The Ministry Of Religion In West Sumatera Province With Quality Of Service As An Intervening Variable. Archives of Business Research 7 (7), 69-87

Kurniawan, H. Heryanto, H. (2019). Effect of Work Discipline and Work Environment on Employee Performance with Work Motivation as an Intervening Variable in Department of Tourism, Youth and Sport of Padang District. Archives of Business Research 7 (7), 88-101

Sari, N. Heryanto, H. (2019). The Effect Of Training And Utilization Of SIPKD On Competency And Its Impact On The Quality Of Financial Statements In Dharmasraya Regency SKPD. Archives of Business Research 7 (7), 112-121 
Fatra, A. Heryanto, A. (2019). The Effect Of Implementation Of Population Administration Policy And Employee Motivation On Quality Of Service And Its Impact On Community Satisfaction In Issuance Of Birth ACCESS (Case in: The Department of Population and Civil Registration of the Dharmasraya Regency). Archives of Business Research 7 (7), 155-165

Yusrisal, Y. Heryanto, H.( 2019). The Influence of Leadership and Competence on Work Motivation and its impact on Employee Performance at the Koto Besar Sub-District Office, Dharmasraya Regency. Archives of Business Research 7 (7), 122-131

Syukri, M. Heryanto, H. (2019). The Influence Of Leadership Style, And Organizational Commitment, On Employee Discipline And Also Its Impact On Employee Performance Of The Dharmasraya District Community And Village Empowerment Office. Archives of Business Research 7 (7), 102-111

Septria, D. Heryanto, H. (2019). Performance Capability Analysis and Regional Budget Evaluation in Implementing Regional Autonomy in Dharmasraya District. Archives of Business Research 7 (7), 180-187

Meldi, M. Heryanto, H. (2019). The Influence Of Quality Of Human Resources And Communication On The Performance Of Civil Servants In The Regional Secretariat Of Dharmasraya Regency With Organizational Commitment As Intervening Variables. Archives of Business Research 7 (7), 132-141

Wahyuni, N. Heryanto, H. (2019). The Effect of Environment and Motivation on Employee Performance with Organizational Culture as an intervening variable on Bank Perkreditan Rakyat Jorong Kampung Tangah Pariaman PT. Archives of Business Research 7 (5)

Khamri, A. Heryanto, H. (2019). The Influence of the Work Environment, Work Discipline on the Spirit of Work and Its Impact on Employee Performance at the Dharmasraya District Health Office. Archives of Business Research 7 (5)

Irvan, RM. Heryanto, H. (2019). The Effect of Competence and Workload on Motivation and Its Impact on the Performance of Civil Servants at the Regional Secretariat of the Regency of Dharmasraya. Archives of Business Research 7 (5)

Jamilus, J. Heryanto, H. (2019). The Effect of Competence, Communication \& Motivation on Employee Performance in People's Welfare Regional Secretariat of Padang City, Indonesia. Archives of Business Research 7 (5)

Zukriah, A. Heryanto, H. (2019). The Effect Of Work Motivation And Discipline On Employee Performance In Human Resources Development Agency, West Sumatera With Education And Training As Variable Intervening. Archives of Business Research 7 (5)

Marunduri, P. Heryanto, H. (2019). Analysis of the Effect of Training and Motivation on Organizational Commitments and Its Impact on Employee Performance (Study on Insurance Marketing Agents on Prudential Agency Pru-Aini Gunung Sitoli PT). Archives of Business

Syamsudirman, S. Yurmain, H. Heryanto, H. (2019). Compensation and Work Culture on Organizational Performance with in mediation by Work Satisfaction in Fire Department Service of Sungai Penuh City. Archives of Business Research 7 (2) 
Heryanto, H. (2019). The Effect of Work Motivation and Work Environment on Performance With Satisfaction as Intervening Variables Education Personnel Rektorate Andalas University. Archives of Business Research 7 (2)

Heryanto, H. Sumarni, S. (2019). The Effect of Certification, Competence, and Motivation on Teachers Performance of Country Civil Apparatus in Sawahlunto City. Archives of Business Research 7 (1)

Eliza, Y. (2015). Pengaruh moralitas individu dan pengendalian internal terhadap kecenderungan kecurangan akuntansi (Studi Empiris Pada SKPD di Kota Padang). Jurnal Akuntansi (Media Riset Akuntansi \& Keuangan) 4 (1), 86-100

Eliza, Y. (2015). Pengaruh Investasi, Angkatan Kerja dan Pengeluaran Pemerintah terhadap Pertumbuhan Ekonomi di Sumatera Barat. PEKBIS (Jurnal Pendidikan Ekonomi Dan Bisnis) 7 (3), 198-208

Eliza, Y. Adriani, E. Maryanti, S. (2019). The Analysis Return on Investment Education of Married Woman in Indonesia. KnE Social Sciences, 667-688-667-688

Maryanti, S. Eliza, Y. Wiyati, R. Thamrin, M. (2018). The Growth of the Population: Labor Potential Mapping in Pekanbaru Indonesia. IOP Conference Series: Earth and Environmental Science 175 (1), 012092

Eliza, Y. (2015). Analisis Kepuasan Masyarakat Atas Kualitas Pelayanan Kantor Kecamatan Siberut Selatan Kabupaten Kepulauan Mentawai. Jurnal Pendidikan Ekonomi dan Bisnis 7 (1), 65-75

Yuharmain, H. Suryana, Y. Novianty, R, Joeliaty. (2016). An Impact Study Of Rural Credit Bank Existence Towards Micro And Small Businesses In Padang City. International Journal Of Scientific \& Technology Research 5 (7), 145-150

Edasa, D. Putra, EE. (2015). Pengaruh Gaya Kepemimpinan, Lingkungan Kerja dan Motivasi Kerja Terhadap Kinerja Pegawai LPP-RRI Bukittinggi. Jurnal Riset Manajemen Bisnis dan Publik 3 (2)

Putra, EE. (2015). Keadilan Dalam Organisasi. Buletin Organisasi dan Aparatur

Putra, EE. (2015). Pentingnya ISO Bagi Lembaga Pendidikan Dan Latihan. Buletin Badan Diklat Prov. Sumatera Barat

Putra, EE. (2015). Urgensi Pengembangan Potensi Aparatur Sipil Negara (ASN). Buletin Badan Diklat Prov. Sumatera Barat

Putra, EE. (2014). The Effect of Human Capital, Structural and Customer Capital to Performance of Small Medium Enterprises at West Sumatera Province. Business Administration at Jose Rizal University

Putra, RY. Marlius, D. (2019). Pengaruh Pendidikan, Pengalaman Kerja dan Etos Kerja Terhadap Kinerja Pegawai Di KPN Batur. Academic Conference For Management 2.

Marlius, D. RD Putra. (2018). Strategi Pengembangan Sulam Bayang. Jurnal Benefita: Ekonomi Pembangunan Manajemen Bisnis Dan Akuntansi. Volume 3. No. 2. Hal. 204-218. 
